\title{
Família em cena: trama, dramas e transformações
}

\author{
Rosana Maria Mohallem Martins ${ }^{1}$
}

Wagner, A. (Coord.). (2002). Família em cena: tramas, dramas e transformações. Petrópolis, RJ: Vozes, 188 p.

Nas últimas décadas a família tem sofrido transformações profundas em sua estrutura e dinâmica, decorrente de mudanças na sociedade. Apesar disso, manifesta grande capacidade de sobrevivência e adaptação, com diferentes arranjos e personagens familiares. O livro traça o perfil das famílias da atualidade, trazendo dados de pesquisas da realidade brasileira. Adriana Wagner, professora da PUCRS, coordenou essa importante obra, que é um convite à reflexão sobre as novas configurações da família brasileira. Foi escrita por diversos autores, mestres e doutores em Psicologia Clínica, sendo a maioria psicoterapeutas, com ampla experiência na área.

O livro é apresentado em três partes. A primeira, intitulada de Cenário, é dedicada à descrição de diferentes configurações familiares; a segunda parte, $O$ Elenco, apresenta as diferentes personagens com textos sobre mães e madrastas, relacionamento fraterno e filho primogênito; e a terceira parte, nomeada de Enredo, mostra as transformações na família.

O primeiro texto da primeira parte, intitulado de Possibilidades e potencialidades da familia - $A$ construção de novos arranjos a partir do recasamento, escrito por Adriana Wagner, aponta para o aparecimento de novas configurações familiares constituídas mediante $\mathrm{O}$ recasamento, quando há a entrada de novos membros na família: padrasto, madrasta, enteado. No estudo realizado pela autora, com adolescentes de famílias intactas/originais e recasadas, os resultados indicaram diferenças na qualidade do relacionamento com a figura paterna, nas figuras de autoridade e na hierarquia familiar. Contudo, essas diferenças não interferem no bem-estar psicológico dos adolescentes. O importante são as regras definidas, limites claros e o diálogo. O que mais desagrada os jovens são as brigas entre família, que independe da configuração familiar.

Luciana Suárez Grzybowski escreve sobre Familias monoparentais - Mulheres divorciadas chefes de familia e constata que o divórcio acarreta transformações na vida das pessoas e a desestabilização causada pode gerar crescimento pessoal dos membros da família. $\mathrm{Na}$ pesquisa da autora, concluiu que as mulheres separadas/divorciadas não estão plenamente satisfeitas com sua condição, demonstrando forte tendência ao fechamento na relação mãe-filho. Isso mostra a importância do valor do casamento para as mulheres e traz a hipótese de uma "pseudo-revolução feminina", mostrando que as inferências sobre a "revolucionária" podem ser preconceituosas, contrapondo com a idéia de que a revolução feminina seria um dos fatores influentes na crise familiar.

Família é para todos? A perspectiva de meninos institucionalizados, escrito por Simone Conceição da Silveira, traz a questão dos meninos institucionalizados e de suas concepções de família. Na pesquisa constatou a idealização e valorização da presença do vínculo familiar desejado, apesar de terem passado por ruptura familiar definitiva ou temporária. Este fato mostra a importância da convivência familiar e do laço afetivo, que supera dificuldades como a miséria e a pobreza. A autora conclui que, seja qual for a configuração familiar, o importante é o vínculo afetivo com uma pessoa significativa, e que as crianças com melhores níveis de saúde emocional são aquelas que, de alguma forma, se sentem pertencentes e incluídas num grupo familiar ou espaço complementar.

Mães e madrastas. Quem são essas personagens? É o texto que abre a segunda parte do livro, com o tema Elenco sendo discutido por Denise Falcke. Atualmente, a madrasta vem sendo uma figura do cotidiano social, cuja inserção na família parece ser um período de ansiedade. Porém, um importante passo é partilhar com o pai a mesma hierarquia e entender sua inserção como um processo gradual. Em relação às mães, é comum sua imagem com atributos de perfeição e de amor incondicional, não podendo ter sentimentos de raiva ou querer investir em questões pessoais. No entanto, estudos mostram que o amor materno não faz parte da natureza feminina, é um sentimento frágil e imperfeito. Por isso, as mães devem se sentir menos culpadas em momentos de tristeza, raiva ou insegurança e devem investir em outras áreas de sua vida.

Luiza Maria de O. Braga Silveira é a autora do texto $O$ relacionamento fraterno e suas características ao longo do ciclo vital da familia, e afirma que o relacionamento fraterno é associado a aspectos positivos e negativos. É uma relação íntima, duradoura e dentro da mesma hierarquia. Oportuniza o aprendizado da disputa, da admiração, da negociação, da cooperação, da inveja, da imitação, do diferenciar-se, do amar, do odiar, do

Endereço para correspondência:

${ }^{1}$ E-mail: rosanamartins4@hotmail.com 
dominar, do ceder. Essas vivências servem de laboratório para as relações sociais que serão experimentadas fora do núcleo familiar. Fatores como sexo dos irmãos, diferença de idade, temperamento, intervenções parentais podem interferir na relação. A autora descreve, desde a infância até a fase adulta, os efeitos dessas interferências.

O filho primogênito - Suas características e seus relacionamentos no contexto familiar é o titulo do trabalho de Adriana Fork Perez, que traz a questão do filho primogênito na relação fraterna. $\mathrm{Na}$ realização do seu estudo observou que os filhos primogênitos, apesar de descreverem na relação um leque amplo de dificuldades, destacam também os aspectos positivos. Acreditam que devem ser o exemplo para os demais irmãos, sentem-se mais responsáveis e mais exigidos pelos genitores. Com isso, apresentam auto-exigência elevada, que pode acarretar melhor desempenho futuro na área profissional. Mostram que aprendem muito no relacionamento fraterno sobre amizade, companheirismo, cumplicidade, negociação, semelhanças e diferenças, como resolver conflitos, como conviver com o grupo de iguais, entre outros.

A terceira parte do livro, cujo tema é Enredo, inicia com o texto de Artur Diehl, O homem e a nova mulher - Novos padrões sexuais de conjugalidade. Conclui que, ao compararmos mulheres do passado com as de hoje, ficam evidentes as conquistas realizadas em relação à sexualidade. Nos últimos anos, fala-se da mulher liberal, independente e desinibida sexualmente, porém parece ter conservado sua sensibilidade e afetividade. O homem, em virtude dessas mudanças, está apresentando problemas na área sexual, está mais companheiro e participativo, mas ainda distante da mulher na área da afetividade. A ênfase que tem sido dada ao homem sexualmente medroso e disfuncional deve ser considerada com cuidado, pois problemas sexuais não são exclusividade de algum tipo de gênero ou sexo, fazem parte da condição humana.
Conversando sobre sexo na família com filhos adolescentes, de Juliana Carmona Predebon, aborda a questão da sexualidade, salientando a importância do diálogo dos pais com os filhos a respeito deste tema. Com essa atitude os pais darão aos filhos maior estrutura e segurança, e estes, conseqüentemente, iniciarão a vida sexual no momento adequado e não serão induzidos pela sociedade ou pelos amigos. Entretanto, os pais têm como tarefa uma reciclagem permanente em relação às mudanças do comportamento sexual do adolescente.

Para finalizar, Denise Falke, José Artur Diehl e Adriana Wagner escrevem sobre a Satisfação conjugal na atualidade. Relatam que, apesar das transformações sociais, a união das pessoas pelo casamento, seja oficializada ou não, ainda parece ser a alternativa para o estabelecimento de um relacionamento conjugal estável. Muitas pessoas, mesmo que tenham passado pelo divórcio, voltam a se casar. Os autores mostram que o investimento na busca de um relacionamento satisfatório faz parte do ciclo vital, sendo um movimento natural de separação de sua família de origem, na busca de um vínculo afetivo.

Concluindo, o modelo tradicional de família, composta por pai, mãe e filho, está sofrendo grandes modificações, que têm alterado sua configuração e funcionamento. É um período de crise. Não anuncia a sua dissolução, mas a sua readaptação e reestruturação de papéis. A capacidade humana de superar situações difíceis e buscar novas formas de equilíbrio possibilita o ajustamento e estruturação de novos arranjos familiares.

A leitura desse livro contribuirá para os profissionais da área, instrumentalizando-os para uma intervenção mais contextualizada, bem como para pessoas interessadas na área. É uma leitura envolvente e instiga muitas reflexões. Vale a pena conferir!

Sobre a autora:

Rosana Maria Mohallem Martins é psicóloga, mestranda do Programa de Mestrado de Psicologia da Universidade São Francisco e professora do Centro Universitário de Itajubá. 